\title{
Siberian punk shall emerge here: Egor Letov and Grazhdanskaia Oborona
}

\author{
Yngvar B. Steinholt \\ Institute of Culture and Literature \\ Tromsø University
}

Dr. Yngvar B. Steinholt (b. 1969) is associate professor of Russian culture and literature at the Institute of Culture and Literature, Troms $\varnothing$ University. He has published a book and several articles on popular music in the Soviet Union and postSoviet Russia and is currently contributing to the research project Post-Socialist Punk at Warwick University.

\begin{abstract}
Any study of punk rock in Russia will in some way come into contact with the massive influence of Egor Letov, his band Grazhdanskaia Oborona, and their massive output during the late 1980s. Academia has thus far been reluctant to study the band because of its leader's involvement with dubious right-wing movements and his many tasteless and provocative media stunts during 1990s. By taking its point of departure in Letov's songs from four stages of his band's development, this article seeks to shed light on Grazhdanskaia Oborona's contribution to the development of punk in Soviet and post-Soviet Russia. When it comes to Letov's extremist views in the latter half of his career it attempts to venture beyond reductionist notions of fascism, into the complex landscape of the paradoxical and often confusing mixture of extreme ideologies that sprang forth from the Soviet collapse. It will appear that Letov's work — his songs - come forth as a lot less contradictory and ideologically extreme than their author's political stunts would suggest. Their aesthetics and ideology are first and foremost punk.
\end{abstract}

\section{Prelude: On approaching security check}

Backstage post gig at the St. Petersburg venue Poligon. It is March 2002, the year after Grazhdanskaia Oborona had their gig at the anarchist squat venue Tacheles in Berlin cancelled. The decisive factor on that occasion was the fascist label applied to the band by Die Zeit's culture columnist. Paradoxically the cancellation happened five years after lead singer Egor Letov broke with the National Bolshevik Party and declared his support for Ziuganov and the reformed communist party during the Russian presidental elections of 1996. Placing his empty beer bottle on the table, a visiting Norwegian fan blurts out his inevitable question to Letov: -“Ty fashist?" (“Are you a fascist?") 
The study of Soviet and Russian rock music has by now gone on for 25 years. Most of it has occupied itself with the canon of russkii rok in Leningrad and Moscow with its band-leading singing poets of safe humanist orientation. At the side of the plate are left those too controversial to fit in our idealised (Western) conceptions of a democratically-minded genre, occupied with the eternal questions of the human experience.

The problems of introducing Igor' 'Egor' Fiodorovich Letov (1964-2008) into the canon of Russian rock poets can be compared to those facing research on Knut Hamsun in literary studies or Leni Riefenstahl in film studies. There are mandatory moral issues to be negotiated before one is allowed to speak of their works. The researcher should also pass the ideological security check and have his/her moral and political position scanned. Unlike the nazi taboo surrounding Hamsun, whose hatred of anything English and love for anything German led to his infamous handshake with Hitler, the fascist taboo applied to Letov stems from his three-year involvement with the National Bolshevik Party (NBP) and a decade of rabid political statements, notably conducted when he was past the peak of his creative output. The stamp has since clung to his name despite his own denial of it. The simplistic fascist stamp which - usually in a western guise which ignores the Russian context of this particular word - has kept Letov outside of the academic study and has also severely delayed research on punk rock in Russia. The article's approach is inspired by the works and methods of theorists such as Philip Tagg (Tagg and Clarida 2003) and Lars Eckstein (2010), who maintain the central importance of musical performance and meaning in our analysis of popular music. This is reflected in its foundation upon the analyses of four songs.

Virtually no band is more central to the development of Russian punk than the initiators of the Siberian punk wave, Egor Letov's Grazhdanskaia Oborona (GrOb). With this article, I am taking Letov's work with me through the academic moral-ethical security check. On checking in I hereby declare that my baggage contains no apologies or justifications. Nor have I packed a final verdict on the case of whether Egor Letov - deep inside his frequently failing heart - was indeed a fascist or not. Firstly, this article attempts to analyse the most influential part of Letov's work: the songs of $\mathrm{GrOb}$ in their development throughout the band's various incarnations. In this, it focuses on finding coherences, rather than exposing violent paradoxes. Secondly, it discusses Letov's political excursions of the mid 1990s in the light of recent research on the National 
Bolshevik Party and extremist nationalist organisations in Russia since that time. In this it seeks to make the reader aware of the vast number of questions that the application of the simple fascist stamp has swept beneath the carpet. These are questions crucial to understanding not only Russian punk rock, but also Russian contemporary culture and society in general. Lest we face them, they will inevitably get us first.

\section{A short declaration of baggage packing and contents}

To misread Russia's controversial characters is the fate of the Western researcher more by default than by accident. We may generously allow 'our own' cultural provocateurs room for ambiguity and ideological balancing acts, but as soon as we turn to Russia, similar strategies and expressions strike us as illogical or frightening, if not outright dangerous. We tend to superimpose verdicts by moral reflex prior to our analysis, effectively prohibiting our own understanding of the matter at hand, as if serious analysis craved the abandoning of moral judgment altogether. This is part of the reason why this article has taken 13 years to materialise.

A second reason for this delay is the tendency in social and cultural studies to disregard the performative dimension of songs in favour of their written lyrics and the biographies of their composers, onto which a matrix of socio-political analysis is superimposed. The current article would not be possible without a more sophisticated, practised and tested approach to the work in question; Letov's songs. In the following analyses emphasis lies on following the logic of the music and its performance - of the work as perceived by the audience - to get a sense of the political context from the work. In short, the songs can provide a context for political statements that are otherwise hard to pin down. The article thus examines the development of $\mathrm{GrOb}$ songs through four stages, all divided by sociopolitical changes, and illustrated by one song from each stage. With a song output as vast as Letov's, four songs are of course far from enough, but the current format allows space for no more. To compensate for the limited number of cases, more than 15 years of listening to $\mathrm{GrOb}$ albums serve to reinforce the findings of the song analyses. Without that listening experience, this piece of research would not have emerged. Now finally, before we turn to the four stages mentioned, I shall provide a brief introduction to Letov and $\mathrm{GrOb}$.

\section{The origins of the man and his band}

Egor Letov was born and grew up in Omsk, a military industrial city in south central Siberia with a population of 1,15 million (1989 census) and 
the cultural facilities of a smalltown. His father taught ideology classes in the Soviet army. His mother died from cancer, aged 53, having been exposed to nuclear radiation in her hometown of Semipalatinsk (near the first Soviet nuclear test site). According to Egor's older brother, the prominent avantgarde-jazz saxophone player Sergei Letov (Letov, S. 2010), both brothers were frequently hospitalised during their childhood. Egor's heart condition, his brother explains, meant that he survived clinical death and reanimation as much as $14^{-15}$ times before succumbing to his final heart failure, whilst asleep, in February 2008. Until he moved to a separate flat three months before his death, Egor was based in the apartment of his father, who allowed him to do much as he pleased; music making and home sound studio included. His brother describes Egor as a silent and introvert personality, but with a vast inner world. The relationship between the brothers was close at times (Sergei was for a few years in the 1990s a regular member of GrOb) but could turn sour for long periods.

The basis for Letov's and GrOb's fame was laid between 1985 and 1991, with a flow of self-released cassettes, which in the mid-90s were re-issued as albums on more than $40 \mathrm{~cd}$ titles. In 1982, in the wake of a short-lived first band project called Adol'f Gitler, he began recording songs with a couple of friends in Omsk. The band played 'a mixture of punk, psychedelia and music from the 60s' (Letov 2001, p. 33) and took the name Posév ('Seed'), possibly from a WWII nazi-collaborator publishing house (Kasakow 2009, p. 19). Here it is necessary to consider the Russian context of the naming. The following example from one of my graduate students exemplifies the gap between Russian and Western attitudes to World War II history and its taboos: a group of foreign students visit a Moscow theme restaurant where customers are waited on by imitators of various historical personalities. The Russians seated at the next table react with loud cheers and laughter when their waiter shows up. He turns out to be serving the students' table as well. The German students are not humoured by their aproned Hitler-lookalike. Another example: in the mid 1990s, it was perfectly possible for a group of Arkhangel'sk boys in their early twenties to name their cellar band Adol'f Gitler and sport stage names such as Giobbels, Gimmler and Gioring, as a mere surface gimmick. The whole concept, seemingly, would be too banal for a proper nazi band, hence it 'just being funny'. The same, of course, would be unthinkable in the West.

If we add to this what forms part of the punk context, nazi imagery was part of the UK punk scene's original set of shock effects, or what Hebdige 
(1979) read as a play with signifiers. The Sex Pistol's Belsen Was a Gas, Siouxsie Sue's and Mark E. Smith's swastika armbands, the origin of band names such as Joy Division, all came as part of the punk parcel. This found a particular resonance in the Soviet Union, where the demonisation of Nazi Germany and the celebration of Victory Day had become a highly ritualised part of official discourse, at times verging on the parodic in its pomposity. As demonstrated by Gabowitsch (2009, pp. 4- 5) this gave rise to an ironic play with nazi images in various segments of the Soviet population, a play where the demonised images were often transposed back on the Soviet state itself. Such play was itself inspired by Soviet popular culture, such as the widely popular TV-series Seventeen Moments of Spring, where Viacheslav Tikhonov played Shtirlitz, a Soviet double agent in wartime Nazi Germany. Interestingly, the series preferred the anachronistic black SS uniforms for their stylistic effect.

Moreover, during the anti-rock campaigns of the early 1980s, Soviet cultural authorities readily applied the term fascism to descriptions of rock bands (including The Sex Pistols, Kiss, and Patti Smith) from the imperialist states of the West. In short, there are at this point too many variables present to establish any direct link between serious neo-nazi or fascist ideology; and the group of teenage friends in remote Omsk, who before re-forming their band as GrOb in 1984 had no access to a stage, no media exposure, and practically no audience. Grazhdanskaia Oborona was named after the primary school classes in civil defence, and abbreviated GrOb ('CofFin') or G.O. Letov and his friend Konstantin 'Kuzia Uo' Riabinov came up with the name on 8th November 1984 and GrOb would become Letov's most productive and enduring band. His other musical projects include: tours and recordings with Ianka Diagileva; the studio project Kommunizm with Oleg Sudakov aka Manager (1988- 90); a series of acoustic solo-albums that for the most part contain versions of $\mathrm{GrOb}$ songs; three albums with the punk-psychedelia project Egor i Opizdenevshie (1990, 1993, and 2000).

The music of $\mathrm{GrOb}$ demonstrates a wide and inclusive definition of punk rock. Although Russian rock musicians were well aware of it, they did not participate in the first punk wave which hit the Eastern bloc from 1977- 80. Thus, by 1984, Russian bands still cultivated notions of punk music and lifestyle related to local experience, as much as pre-defined conceptions of punk in its western form. Musically, early Russian punk music was mixed with elements of post-punk and new-wave, ska, even new romantics (as demonstrated by Leningrad bands Avtomaticheskie 
Udovletvoriteli, Strannye igry, and Kino respectively). A common misinterpretation among scholars studying rock in 1980s Russia, is that the music sounds different because musicians were poorly informed of western rock genres, styles, and conventions. This is far from the case. In general, the Russian rock generation of the 1980s was quite well-informed and conscious about the stylistic spectre of rock, perhaps even more acutely so than a western rock fan. If Russian rock sounds different, it is partly because of technical equipment and recording methods, but chiefly because Russian bands saw rock as a vehicle to express local experience in their own language (see also Steinholt 2005). Only towards the end of the 1980s would Russian punk conform to more widely established genre conventions. GrOb's influence on the development of Russian punk rock was massive. Here, the band also contributed to cultivating the local characteristics of the genre.

\section{Stage 1. Underground games with consequences}

From the founding of GrOb in November 1984 and up until the band's live debut in 1987, a handful of magnitoal'bomy (home-recorded albums on tape) were recorded, amongst them a re-recording of Posev's Poganaia molodëzh' (Disgusting Youth, 1984), Optimizm (1985), and the acoustic Igra $v$ biser pered svin'iami (A game of marbles before swine, 1986). Musically, Poganaia molodezh' is the closest GrOb got to the British realpunk canon, yet it is already coloured by Russian 'folk' harmonies and quotes from Soviet schlagers. The two latter albums are, strictly speaking, reggae played acoustically with a punk spirit and a touch of Russian ballad. GrOb were frequently quoting from Soviet pop, folk, pseudo-folk, military, and representational music. Thus, the early songs play actively on Soviet musical forms shunned by most Russian rock bands at the time.

This adds to the playful irony of early GrOb songs. They do in retrospect sound happier, perhaps even innocent, compared to the extremes that were to follow, but the array of musical and lyrical shock effects are already there: distortion, dissonances, intense vocal deliveries, barks and screams, vigorous anti-sovietisms, swearing, anarchy, death, war, suicide, and the abject.

In Klenovyi list (1985) the protagonist is a personified maple leaf, mercilessly torn from its twig and discarded by the wind, then crushed under the crowd's stamping feet, before it has its sickly nerves ripped out by the hands of playing children. Ascribed no value by either wind, crowd, or children, the bleeding leaf faces violent destruction. By contrast, the melody is in the major key - with the notable exception of the guitar solo 
quoting the evergreen Podmoskovnye vechera (Evenings near Moscow). In the verses the throaty vocals hold nearly celebratory, even chuckling qualities, and in the refrain express a mild, tired regret rather than selfpity or melancholy. The absence of lament becomes demonstrative in the final vocal chorus break of 'baraparapara's', which expresses even the performing voices' disregard for the leaf's value; a celebration of the protagonist's demise, and an ironic distance to the song's very motif. The quote of the famous schlager and the theme of autumn suggest that Klenovyi list is simultaneously a punk answer to the Soviet estrada's countless 'songs about the weather'. The word 'estrada' ('small stage') refers to Soviet (as well as contemporary Russian) pop and dance music. In late Soviet times, pop songs were not to deal with political topics (including existential questions which might or might not conflict with official ideology), nor should they make too obvious references to physical love, nor focus too much on the individual. As a consequence of these limitations, the estrada genre was dominated by songs which, in their essence, were about nothing much in particular and to which standardised metaphors of weather, nature, and changing seasons became the norm. If rock in Soviet Russia had the character of a rebellion, it first and foremost rebelled against the estrada's sweet, smiling emptiness.

To the contemporary Omsk security apparatus, even a song such as Klenovyj list appeared all but innocent. When it came to rock, the provinces were far less easy-going than Leningrad, and even there punk rock was not tolerated. In the Siberian provinces, bored KGB-officers struggled to deliver results, and were prone to inventing threats. To them, possible anti-Soviet activities in a home recording studio were a serious matter.

Here, as historic reality merges with the artistic project, facts with myths, the canonical tale of $\mathrm{GrOb}$ and Letov becomes harder to verify. According to the more sober accounts (found by comparing and combining information from collected interviews [Letov 2001]), GrOb came under KGB investigation; Riabinov was sent off for army service in a restricted area; Letov was examined at a mental hospital. Following this, Letov's friends and band-members were restricted from seeing him. He taught himself to play the drums and recorded a string of albums on his own, including Totalitarizm (Totalitarianism), Myshelovka (The Mousetrap), and Krasnyi al'bom (The red album). Here, the antisovietisms become a lot sharper, the irony turns to sarcasm, and Letov's voice often cracks in shrill anger and despair: hallmarks of GrOb's second stage. 


\section{Stage 2. Perestroika: an age of unlimited creativity}

The second half of the 1980s saw rock music enter Soviet stages following the implementation of Perestroika and Glasnost. By the end of the decade Russian rock (russkii rok) had reached a peak of popularity. Simultaneously it also arguably exhausted its most wide-ranging appeal. By 1990 russkii rok had lost much of its controversial aura, the fiercest debates about the phenomenon had long since stilled, and the general interest in it began dropping. Yet during these few years, many rock bands and artists reached a creative high.

Gradually, rock started winning acceptance outside the major cities. In spring 1987, the first ever Novosibirsk rock festival was held. The local Komsomol (also abbreviated VLKSM, the youth organisation of the CPSU) rejected a few bands on short notice, leaving a hole in the programme. Thus, GrOb got 20- 25 minutes to play before the power was cut. The consequences of the interrupted performance reputedly included Letov being hospitalised in a psychiatric unit, from which he later fled. For a few months, until the police search for him was lifted, he hitch-hiked across the USSR in company with fellow singer Ianka Diagileva, playing kvartirniki (concerts in private flats). Upon returning to his Omsk home, he recorded the albums Tak zakalialas' stal' (Thus the steel was tempered, 1988) and Vse idet po planu (Everything's according to plan, 1988).

Then, in 1989-90, came a rush of albums in a peak of productivity that for most fans cemented what GrOb was about. Here, the whole energy potential of the band's music is unfolded in amplified distortion. But even in hardcore punk or trash-punk songs, GrOb's trademark harmonies and flair for musical quotes are notable. Compared to the russkii rok tradition of Moscow and Leningrad, the punk rock of GrOb stands out in a number of respects. As mentioned, Letov utilised the non-rock genres of Soviet music in frequent quotes and parodies. His melodies were at times folkoriented, but always performed in a punk mode. On the other hand, especially around the creative peak of 1988-90, he was acutely aware of the genre codes of anarcho-punk in the west. GrOb's discovery of The Dead Kennedys and the Alternative Tentacles label is, for example, instantly reflected in their guitar sound. Musical and lyrical bricolage is one of punk's original traits, and a format in which Letov excels. This partly explains his enormous output during these few years. Slogans, quotes from songs and poetry, swearwords, sayings, newspaper headlines, exclamations are combined with Letov's own minimalist poetic phrases, usually with a particular emphasis on phonetic effect, force, and 
performative appeal. At times the lyrics have storytelling qualities similar to Jello Biafra's (Dead Kennedys); others carry out impersonations of negative characters and phenomena with a deadpan irony reminiscent of the Wright Brothers (NoMeansNo). Still other songs even approach the bard song format, but most frequently the lyrics merely build up under one main punchline, serving to give priority to a single overarching exclamation.

The lyrics' ensuing deficit of meaning is filled partly by vocal and instrumental performance, partly by the sum of Letov's own output, but no less by the music's generic references. Letov: 'You cannot regard your own culture outside the context of world culture' (Letov 2001, p. 13). This is reflected in the fact that, in my 15 years of introducing Russian bands to non-Russians, GrOb songs have proven to be those most easily understood and appreciated. They hit a vain of recognition in listeners familiar with various punk rock formats, whilst adding enough local references to create an effect of 'exoticism'. The songs sound familiar, yet fresh, and Letov's intense vocal performance adds a sense of urgency that transcends the language barrier: the listener recognises in Letov's voice his/her own experience, and makes sense of it through generic recognition.

Letov's voice follows up the musical powersurge. It takes on a nerveshattering desperation which leaves little room for fine irony. This is as direct, literal and exclamatory as his lyrics get. Thematically as well, familiar concepts are brought to their extremes in lines such as: 'We're gonna die and you're gonna watch' or 'War or peace? War! / Love or fear? Fear!' The albums of GrOb's second phase form the soundtrack to the late Perestroikan collapse of ideological language; a process highlighted by the desecration of the ultimate Soviet symbol, Lenin. In Pesnia o Lenine (The song about Lenin, 1989) Lenin is compared with inter alia Hitler, Stalin, Mao, Christ, Abel and Cain, Yin and Yan, and Tao. He is, sings Letov, 'the jokes they fool us with [...] the bait they pull us with [...] the hands they sculpt us with [...] the ray that blinds us [...] the tanks that subdue us [...] our poisoned truth [...] our healing bullet [...] our crippling fear,' and ultimately: 'the arse in which we stink' and 'the blood we're sucking'. The staccato lines are reeled out at breathtaking speed with a voice sneering of throaty disgust. The refrains consist of the famous Soviet slogan 'Lenin lived, Lenin lives, Lenin shall live!', repeated ever faster, until the vocals 'get stuck' repeating 'shall, shall, shall,' then becoming a pain-inducing howl. Lenin shall live at the protagonist's expense. The intensity of the vocal performance unites the paradoxes of the lyrics in a single scream of sarcasm, simultaneously unsettling, empowering, and hilarious. 


\section{Stage 3. The dawn and demise of 'true revolutionaries'}

Between 1991 and 1997 GrOb released only four albums, all compilations and live recordings. Letov gave his priorities to the recording of two albums with his side-project Egor i opizdenevshie. On these records the music calmed, approached psychedelia, and played further with Russian popular and traditional harmonies, while the lyrics tended towards more traditional poetic forms. Thus, the next GrOb studio albums to emerge were Solntsevorot and Nevynosimaia legkost' bytiia (Solstice and The Unbearable Lightness of Being, both 1997). Save for the familiar guitar sound and Letov's characteristic voice, little was left of GrOb's hardcore punk of seven years before.

In the meantime, Letov embarked on a political career that would mark him as controversial in a manner his work itself had yet to achieve. This saw him as one of the co-founders of the National Bolshevik Party (NBP). With - among others - avant-garde composer and former member of the legendary Leningrad rock band Akvarium, Sergei Kurekhin, he formed an organisation for revolutionary culture, Russkii Proryv ('Russian Breakthrough'), which collectively joined the freshly-started NBP in 1994 as its 'cultural wing'.

No doubt, it would be entirely appropriate to call the NBP in its initial form a fascistoid organisation. However, if the term 'fascism' is applied in the usual manner of an academic stop sign it will not serve our understanding. The NBP's initial programme represents a grotesque idealisation of the murkiest aspects of Russianness. As such, it can tell us more about Russian culture than we may be willing to learn. It is written in an artistic and theatrical style. The language carries the unmistakeable mark of literary works by the movement's leader; a man who described his highest moment of happiness as coming as a poor Soviet emigrant to the US and being penetrated by a big and strong African-American in the sandbox of a New York playground (Limonov 1979). The author Eduard Limonov (real name Savenko) had returned to Russia in 1991, determined to benefit politically from the cult status he had earned by publishing his scandalous autobiographical novels in exile. Roesen (2008, p. 113) suggests that his motive for entering into politics was the creation of a massive Gesamtkunstwerk that would cement his position as a provocative author. If so, Limonov can be compared to another author-provocateur, Igor' Iarkevich, who carved a niche for himself in post-Soviet literature by consistently breaking the sexual taboos of Russian language. Iarkevitch parodies the politically significant author by posing as an onanist, who is 
doomed to failure because he can never be Solzhenitsyn. Where Iarkevitch targeted sexual taboos, Limonov embarked on a similar project, but concentrated first and foremost on ideological taboos, openly blending symbols of Soviet communism and nazism. The career strategies of both these anti-Solzhenitsyns might be tasteless in the extreme, but they are in many ways symptomatic of the development of Russian culture in the immediate wake of the Soviet collapse. Each in its own way, they also proved quite successful.

Immediately after his return to Russia, Limonov was briefly involved in the party leadership of Zhirinovskii's LDPR, with which he was soon disenchanted despite his swift rise to party prominence. In late 1993 he thus went on to found his own party, the NBP, together with a certain Aleksandr Dugin. Dugin was a self-appointed left-wing fascist thinker and mystic neo-eurasianist. He had become disillusioned with the Pamiat' movement, in which he was involved from 1987- 89. Limonov took the role as undisputable party leader and future dictator, Dugin the role as chief ideologist. The NBP sought to unite what they referred to as revolutionary extremists of the far left and far right. This is reflected in the party banner's synthesis of Nazi-German and Soviet imagery: a black hammer and sickle in a white circle on a red background. Another symbol of the movement was the hand grenade, or limonchik ('little lemon') in Russian argot. In Limonov's own words, National Bolshevism was conceived as a '[s]upercontemporary radicalism in arts and politics' (Limonov in Sokolov 2006, p. 147).

The NBP actively sought cooperation during its formative years (i.e. until Dugin's departure in 1998) with nationalist organisations of the extreme right. Still, it deviates from violent fascist groupings such as the RNE (Russkoe Natsional'noe Edinstvo, 'Russian National Unity') in a number of significant ways. One is its relative lack of interest in ethnicity and racist polemics (including antisemitism). This tendency, notably, does not exclude either the enthusiastic defence of fascist regimes, nor scattered racist comments in NBP writings, nor, as Shenfield points out, can it hide the ariosophic stream in Dugin's ideological mysticism (Shenfield 2001, pp. 196- 7). To Limonov, on the other hand, being Russian is a matter of patriotic creed rather than one of blood (Shenfield 2001, p. 212). Another crucial point where the NBP deviates from other nationalist groupings is in its ideas about the free status and active role of culture, which is in turn linked to a third point; namely the inherent potential of self-irony. This comes through in Limonov's praise of violence as a positive quality in itself. Here he is confronted by his own humanist 'weakness' and what he 
regards as the endemic servility and sentimentality of the Russian people, which prompt him to indulge in frustrated self-derogatory polemics most unfitting for a party dictator (Shenfield 2001, p. 206).

The main enemies of the NBP were initially the old party nomenklatura and the old cultural elite, who after the collapse of the Soviet Union became the new bourgeoisie. These also serve as the primary enemies of state in the original NBP programme alongside their liberal-democratic allies in the Yeltsin administration and in the West, represented by the 'Great Satan' - USA, the EU, and their NATO and UN incarnations (Kulavig 2008, p. 98, Sokolov 2006). The NBP's calls for violence were directed towards these opponents in the form of revolution, unlike the RNE's badly concealed and violent targeting of ethnic groups and foreigners. Sokolov describes this difference in Bourdieuan terms: where the RNE sought to gain political capital exclusively through demonstration of a capital of force, the NBP sought the same goal by displaying the cultural capital of its leaders and followers, whilst simultaneously boosting their careers. According to Sokolov, Limonov's main achievement was to sense and act on the emerging, self-made cultural elite's hatred against the enduring hegemony of a new bourgeoisie, formed from the old Soviet etablishment. To this one might add the frustration following Yeltsin's violent subduing of his legally elected parliament in the autumn of 1993 (RNE's Barkashov was among the surviving defenders), as well as the first manifestations of a Soviet nostalgia that Putin would later institutionalise. In this context Limonov praised punk for its youthful aggression (Limonov 1993, pp. 326-33), a position he would later expand to incorporate rock music as such as a vehicle for nationalist sentiment (Shenfield 2001, p. 218). Interestingly, the idea of rock music as suitable for official representation was subsequently adopted by the Putin and Medvedev administrations (See Wickström and Steinholt 2009).

This is the background for Letov's speech on behalf of Russkii proryv at the so-called 'Meeting of Leftist Forces' in Moscow in 1994. Seated between Limonov and Dugin, alongside RNE's Barkashov and other nationalists, he declares:

A war rages, spanning the whole history of humanity [...], a war between enflaming, creative, constructive forces, forces of order, let's say, and forces of chaos, anarchy, destruction, stasis, death [...]. So, my presence here demonstrates [...] that I made my choice already long ago. We stand up, all our movement, for just that side of order, the creative, constructive forces of the sun. A new 
proletarian revolution is brewing, a righteous and final revolution, and I believe that if we -extremists, radical nationalists, and radical communists- unite our forces, victory will be ours!

[Russkii proryv] consists of [...] those [...] who resist the very principle of the Babylonian civilisation that rules our world, and also resist the rules of the game and the very stasis of life imposed on them by the powers. Our movement consists of those very people who share our views, our ideas, and system of values. That is, strictly speaking, the eternal revolutionaries and extremists. (www.youtube.com: 'Elementy: sobranie levykh sil')

Asked if he is not surprised to be seated alongside communists and fascists, he answers: 'No, [...] because we all confess to a system of values that unites people, does not divide them. Both communists and fascists' (ibid.). Letov, referring to himself as a nationalist-communist, is then prompted to explain what nationalism means to him: 'I believe that during 70 years of Soviet power a new mentality arose, a new people - the Soviet people. I am a Soviet nationalist. There is a principle of nationalism of blood, there is a principle of nationalism of territory, that [last one] is the imperial principle' (ibid.). Finally, a member of the audience asks him to describe the right-wing radical movements among young people in Siberia: 'I can unequivocally say that there is one goal - that is the movement towards national communism or even towards fascism, to be honest. [There are many] such youths, and they keep phoning me, asking me to help them, to introduce them to influential people in Moscow, to Barkashov and so on. People are waiting for the order' (ibid.).

What is implied by Letov's records being sold from a table next to RNEs racist propaganda? Was, as Gabowitch $(2009$, p. 6) asks, the NBP at this point a right-wing project to infest the left with fascist ideology, or a leftwing project that utilised right-wing imagery in order to shock and provoke? It was probably both simultaneously, and it gained a considerable part of its momentum from being persistently unclear about its true colours. Similarly to the position of bands such as Laibach or Avia (see Yurchak 2006, pp. 252-4), whose aesthetics speculated in a lack of ideological explicitness, the whole point would be to maintain a painfully disquieting ideological ambivalence. Ultimately, anyone who concludes that the phenomenon belongs to this or that side will be the laughing stock of the insider. This kind of effect, defined by Yurchak as stiob in a strict sense, was cultivated in a variety of ways in late Soviet and early post-Soviet culture. Here, the straight-faced form of irony entails an over- 
identification with the ridiculed to the extent that doubt arises as to whether the performer is indeed supporting or opposing it. This presupposes a position where the performer simultaneously reproduces and ridicules the same phenomenon.

Whether such potential was foreseen by the initiators or not, Limonov and Dugin's recipe for an extreme political party turned out to be a highly inflammable mixture. It attracted scores of young Russians, members and activists whose various views and activities often bore witness to the depth of the NBP's inherent paradoxes. Even neo-nazis tend to speak favourably about the organisation's spirit, although they would never want to be associated with the openly gay Limonov. Whatever the initial intention, the NBP quickly became Russia's largest youth movement without government backing. Its following was all but unitary, and surely not all would subscribe to a Krasnodar member's personal interpretation of the three-letter abbreviation: 'Nado Bol'she Pit" ([You] must drink more'). Therefore, as Gabowitsch argues, the idea does not hold that the NBP was merely a work of straight-faced ironic manipulation of ambiguous symbols to promote fascist ideas on the contemporary culturalpolitical scene. Simultaneously neither can it be regarded as simply a straight-faced ironic play, undeservedly misunderstood by those without sufficient intelligence and sense of humour (Gabowitsch 2009, p. 7). Only much later, since the departure of Dugin and his followers in 1998 and the 2004 introduction of Abel' Liberman's pro-democratic programme, did the NBP move significantly in the direction of the leftist democratic opposition and alterglobalist NGOs (Verkhovskii, Kozhevnikova et al. 2009, p. 293). During the demonstrations leading up to the 2007 presidental elections the NBP partook actively in the so-called Dissenters Marches alongside the liberal extra-parliamentary opposition. Limonov has denounced historical and contemporary fascism as opposed to the cause of the NBP and declared that as a leader he is obliged to follow the course set by the public opinion 'like the needle of a compass' (Verkhovskii, Kozhevnikova et al. 2009, p. 298). In spite of such a radical change of mind, however, he has insisted that the initial programme remains valid. Ironically, the NBP was banned in 2007 by the presidental administration it turned against, and which profited from many of Dugin's and Limonov's initial ideas.

Songs Letov released in 1989-91 do not only echo the sentiment recognised from western anarcho punk: 'I don't need your fucking world / This world brings me down / I'm looking forward to death' (The Dead Kennedys, 1980). Their misanthropic stance also comes close to Dugin's ideas of death as a heroic revolutionary means to destroy present evil 
society and create a new one, based on love (Shenfield 2001, p. 197). Also, Limonov's literary shock aesthetics, as well as his ambivalent mixture of heroism and self-humiliation, have much in common, not only with Letov's, but with Russian punk aesthetics in general. Ideally, to the Russian punk, the value of the fight lies not in victory, but in the ability to engage wholeheartedly in the losing side. Status is gained through being beaten to pulp by an overpowering opposition, by suffering humiliation, by performing acts of self-debasement. GrOb's chorus 'We're gonna die and you're gonna watch' relates to this as much as Limonov's autobiographical self-humiliation did. Thus, the temporary alliance of these highly diverse controversial figures is perhaps not so surprising.

In this context the involvement of Sergei Kurekhin in Russkii proryv, and his (unsuccessful) promotion of Dugin for the 1995 duma elections, also deserves mention. One of Kurekhin's well-remembered media stunts involved a TV appearance where he posed as a historian. Based on the works of Carlos Castaneda, he argued with gradually fading deadpan, that Lenin, through the consumption of hallucinogenic mushrooms transformed into a radio-transmitting fungus. As with all his artistic projects (such as the inclusion of farm animals in the live performances of his band Pop Mekhanika), Kurekhin's involvement with Russkii proryv and the NBP had undeniable humorous aspects. This is not to say that everybody found the joke funny. In 2001, when long time Akvarium photographer Andrei Usov showed me his pictures from Kurekhin's funeral, I asked him why all those 'boneheads' had turned up for the ceremony. Usov answered with deep-felt regret that Kurekhin's jokes had finally gone too far and made him friends among the wrong kind of people.

It was shortly after Kurekhin's untimely death in 1996, that Letov left the National Bolsheviks and declared his support for Ziuganov's Communist Party. Also, in interviews since 1997, its frontman enthused about GrOb spending four years intensely exploring LSD, beginning in 1993 and ending with the recording of the album Nevynosimaia legkost' bytiia (1997). During the entire recording process, he claims, every note was played under the influence of drugs (Letov 2001, pp. 212-4). According to his brother Sergei, however, Egor did not take drugs on a regular basis because of his heart condition, with the regrettable exception of alcohol (Letov, S. 2010). Another example of Egor Letov's self-mythologising or a too optimistic analysis by his brother? Whatever the case, the record sounds like Egor's version might be closer to reality.

Musically, dramatic change has indeed taken place here. The music of the 
album's opening song, Poi revoliutsiia (Sing revolution), has obvious anthem-alluding qualities. Its lyrics are oddly pompous and stilted, and loaded with poetic cliches: 'A living rain crossed the field / Hobbled over frozen cheeks / Raised those who had died young / To the last uneven battle.' In the bridge leading to the refrain, though, the intensity of Letov's performance (voice roaring, cracking, and screaming) breaks the format and adds punk urgency to the song. The accompaniment is restrained, but the guitar sound carries the familiar distorted fuzz. The quality of the recording is - if possible - even lower than before, sound enveloped in a cardboard-alluding, claustrophobic space. In a 1993 interview Letov describes his musical style-change as a shift from ultra-expressive punk towards both Soviet estrada songs and western rock of the 1960s: 'I always loved, listened to, and collected that music' (Letov 2001, p. 132).

Poi revoliutsiia, this fuzzy Soviet-style panegyric to the ressurection of the true revolutionaries, verges on the parodic, yet failed to amuse the contemporary audience. Still, while the lyrics over-identify with Soviet popular song of the 60s, Letov's voice has regained its chuckles and ironic ambiguity. It also evokes the motif of a Duginesque, heroic, revolutionary death and rebirth, opening a range of possibilities as to what or whom the chuckles are meant for. Intended or not, these are qualities which save the album from being read as trite, nationalist-communist propaganda. Unfortunately for Letov, his venture into politics and association first with the NBP, then Ziuganov's communists, had already made him uninteresting to most members of his own generation, and severed his once wide-ranging audience appeal. In 2001, St Petersburg rock critic Andrei Burlaka expressed disappointment with Letov's development since he ventured into politics, that his music stagnated and all resources went into re-releases of Kommunizm and useless live recordings. To Letov himself, however, as he repeatedly stated, his 'political shifts' were all but contradictory. He still attacked the same corrupt people of the nomenklatura, once the high-caste of Soviet Power, now the politicaleconomical elite of Yelstin's Russia: enemies of the true revolutionary. His change of masks was merely an answer to that of those in power. On the other hand, engaging in Realpolitik was never looked upon as a sensible move in a Russian cultural underground shaped by Soviet reality. It proved more disqualifying than rewarding, and Letov's message soon lost its general appeal.

\section{Stage 4. Back to nature}

Following Sokolov's (2006) argument, the members of the new, self-made, cultural elite who got involved with the NBP, used it to promote their 
careers and increase their public visibility, and then - with the notable exception of Limonov himself (whether he was absorbed by or chose to remain in his Gesamtkunstwerk) - moved on. In Letov's case, his NBP fling did attract thousands of new teenage natsbol fans, but also a lot of problems. His music remained excluded from public broadcasting. Concerts both in Russia and abroad were being cancelled because of his alleged fascism. In Russia, the events attracted both fans with varying devotion to the cause of universal extremism, and simply hooligans who made a habit of destroying the band's concert venues. It soon proved to be a challenge to find suitable concert stages, not least in Moscow. As this distance between performer intentions and audience expectations increased, limiting the band's activities, Letov - disabled by his past media stunts - could do little but sigh during interviews:

[A Dutch fan] said that he doesn't care whether we are communists or fascists, that what's important is that we express emotions that he constantly experiences. We expressed and express those emotions, but people who experience them are becoming rare (Letov 2001, p. 212).

Thus, for the last seven years of his life and career, Egor Letov declared himself apolitical. Whatever they may have been, he kept his politics strictly to himself. What remained was an ecologically based misanthropy, combined with some sort of a slavonic, psychedelic, natural paradise that can be reached only through the dissolution of the ego. On the prepenultimate album, Zvezdopad (Starfall), GrOb recorded cover versions of songs by the bards of the Soviet era. Then followed two full-sounding studio albums, Reanimatsiia (Reanimantion, 2004) and Zachem sniatsia sny (Why are dreams dreamt, 2007), which give the impression of a band that has settled down and found its style, closer to its interpretation of 1960s psychedelic rock, yet still retaining notable estrada influences.

In Tanets dlia mertvykh (Dance for the dead, 2007), the artist-protagonist has reached his earthly paradise - through metaphoric death. The rebel extremist has laid down his sword and returned home, only his voice remains, sharp, yet gently chuckling: 'And the corpse walks the earth / Proud / Rustles the paper, surfs the Internet / Happily goes to the shop / Celebratory to watch football / Nights in bed with wife.' In its songs the corpse still contemplates the human condition's fears and laughs. It continues to create light and sounds, through which it will re-emerge: 'I shall emerge here'. 


\section{Conclusion}

The constants in Egor Letov's career with GrOb may not be immediately apparent, but they do exist beyond the artist's personal interpretation. By giving more attention to the actual songs and the vocal and instrumental performance of them, one achieves a clearer and more consistent picture of Letov's work. His music has been labelled 'suicide punk,' based on one of its most frequently recurring motifs. During the four stages described, the theme of the death of the ego has adapted to the changing social environment via pre-perestroika and perestroika USSR, to post-Soviet Russia in the ages of Yeltsin and Putin. The death of the ego:

-as forced upon you by an oppressive government;

-as a celebratory act of resistance;

-as its dissolution into a mass movement;

-as the destruction of the revolutionary hero;

-as its dissolution into nature or everyday life.

Returning to the backstage of the Poligon in March 2002, the question raised by the Norwegian fan provokes the following reaction: The whole band, including the small-grown, pale, bearded, long-haired sibiriak dressed in Che Guevara T-shirt and sporting thick babushka-design glasses, erupt in roaring laughter. -"No," chuckles the band leader. "But," continues the fan from abroad, "what was this thing with Limonov?" -"That was about something entirely different." Here, Letov embarked on a lengthy explanation in his characteristic fast, slurred, Siberian accent, full of reference points and name dropping that his merry guest from the West was sadly unable to comprehend.

To be a bit cynical, this, of course, proves no more that in March 2002 Letov did not himself define his previous activities with the NBP as agitating fascism. More interesting here is the material we have carried through the moral security check - Letov's work. In that whole complexity of songs on all the albums of GrOb, listened to within its generic context and allowing Letov the same amount of tolerance as we would a Rotten, a Biafra, or a Rollins, I maintain I can find no single evidence of racism, neo-nazism, or fascism. Letov simply does not sing it. Obviously, Russians have different lines in the sand as to what can be expressed in radical statements. In a Russian understanding, there is nothing wrong with the idea of an empire and it is fully possible to be an imperialist without being racist. We may well resent such views. Nonetheless, any future interpretation of Letov's position as 'fascist' should be grounded in further analysis of his work and of concepts such as 'national communism,' 'territorial nationalism', and 'Soviet nationalist'; not in a combination of 
poorly-hidden russophobia combined with scattered examples of provocative quotes and media stunts, scrutinized through the astigmatic lenses of a closed eurocentric socio-political context. I may be wrong, but to me a glowing, universal misanthropy combined with anti-social tendencies match poorly with the personal qualities I normally associate with fascism.

In September 2007, When GrOb arrived in Norway for what would turn out to be their last performances outside Russia, I asked Letov to reconsider his refusal to speak to the local press. He stated: 'I don't give interviews, because I can't keep myself from saying what I think. And if I say what I think, there'll be no concert.' Accepting the wishes of a man disillusioned by the consequences of fifteen years of on-the-edge media acrobatics, I left it at that. Regrettably, facing the manager's insistence on shielding his client from questions, I also put any plans of an interview for my research on hold. During their stay, the questions posed by Letov and his wife, Natal'ia Chumakova, centered on Saami culture and Norwegian forest cats. Excursions into the 'local nature' topped the band's wish list. GrOb were invited to a concert with the band Adjagas, whose combination of traditional Saami vocals and indie-folk-rock left a strong impression on the guests. There was little punk about Egor Letov's appearance. Long hair as always, beard, glasses. A quiet, introvert, sibiriak of frail health who kept his views strictly to himself. Only on stage was Letov's voice as powerful and nerve-shattering as ever. He emerged there.

This article is part of the ongoing research project Post-Socialist Punk: Beyond the Double Irony of Self-Debasement, funded by the Arts and Humanities Research Council. Thanks to Ivan Gololobov, Erlend Hagan, and Hilary Pilkington for their contributions.

\section{Bibliography}

Eckstein, L. 2010. Reading Song Lyrics. (Amsterdam/NY, Rodopi)

Gabowitsch, M. 2009. 'Fascism as Stiob'. Kultura, 4, pp. 3-7

Hebdige, D. 1979. Subculture: The Meaning of Style, (London, Routledge)

Kasakow, E. 2009. 'Models of 'Taboo Breaking' in Russian Rock Music:

The Ambivalence of the "Politically Incorrect". Kultura, 4, pp. 19-22.

Kulavig, E. 2008. 'Nationalisterne i Putins Rusland'. Den Jyske Historiker no. $117-118$ pp. $87-102$

Laruelle, M. 2009. In the Name of the Nation: Nationalism and Politics in Contemporary Russia, (New York, Palgrave Macmillan) 
Letov, E. 2001. Ia ne veriu v anarkhiiu, (Moscow, Skit International)

Limonov, E. 1993. Ubiistvo chasovogo, (Moscow, Molodaia gvardiia)

Limonov, E. 1979. Eto ia Edichka, (New York, Index Publishing)

Roesen, T. 2008. 'Det nye Ruslands litteratur' Den Jyske Historiker no.

117-118 pp. $103-119$

Shenfield, S. 2001. Russian Fascism: Traditions, tendencies, movements, (London and New York, M. E. Sharpe)

Sokolov, M. 2006. 'Natsional-bol'shevikskaia partiia: ideologicheskaia evoliutsiia i politicheskii stil", in Russkii natsionalizm: ideologiia $i$ nastroenie, ed. A. Verkhovskii (Moscow, SOVA), pp. 139-65

Steinholt, Y. 2005. Rock in the Reservation: Songs from the Leningrad Rock Club 1981-86, (Bergen and New York, MMMSP)

Tagg, P. and B. Clarida 2003. Ten Little Title Tunes. (NY, MMMSP)

Toporova, A. 1999. "Natsboly" v Sankt-Peterburge: obrazy i

povsednevnost", in Molodezhnye dvizheniia i subkul'tury Sankt-

Peterburga, ed. V. Kostiushev (St. Petersburg, Norma), pp. 117-27

Turovskaya, M. 2009. 'The Swastika and Us: Questions without

Answers'. Kultura, 4, pp. 8-13

Verkhovskiy, A., G. Kozhevnikova et al. (eds.) 2009. Radikal'nyi russkii natsionalizm: Struktury, idei, litsa, (Moscow, SOVA)

Wickstrom, D. and Y. Steinholt 2009. 'Visions of the (Holy) Motherland in

Contemporary Russian Popular Music: Nostalgia, Patriotism, Religion and

Russkii Rok' Popular Music and Society, 32, 3, pp. 313-330

Yurchak, A. 2006. Everything Was Forever Until It Was No More: The Last

Soviet Generation. (Princeton and Oxford, Princeton University Press)

\section{Music}

Grazhdanskaia Oborona, 'Klenovyi list', Optimizm. Misteriia zvuka. 1985

Grazhdanskaia Oborona, 'Voina', Voina. Misteriia zvuka. 1989

Grazhdanskaia Oborona, 'Pesnia o Lenine', Voina. Misteriia zvuka. 1989

Grazhdanskaia Oborona, 'My budem umirat' (a vy nabliudat')', Pesni

radosti $i$ schast’ia. Misteriia zvuka. 1989

Grazhdanskaia Oborona, 'Poi Revoliutsiia', Nevynosimaia legkost' bytiia.

GrOb Records. 1997

Grazhdanskaia Oborona, 'Tanets dlia mertvykh', Zachem sniatsia sny.

Khor. 2007

The Dead Kennedys, 'Forward to Death', Fresh Fruit for Rotting

Vegetables. Cherry Red. AMG R 634081. 1980

\section{Internet sources and links}

Adjagas band homepage: http://www.myspace.com/adjagas

Sergei Kurekhin's stunt 'Lenin was a mushroom': 
http://www.youtube.com/watch?v=h2cs8QLnxlU

Egor Letov's speech on behalf of Russkii proryv at 'Elementy - Sobranie levykh sil,' DK Oktiabr, Moskva, 1994 (with Limonov, Dugin, Barkashov, Anpilov):

http://www.youtube.com/watch?v=HJPtQ0NZsYg\&feature=related

Sergei Letov, interview 2010:

http://lenenomaniya.ucoz.ru/news/sergej_letov_intervjunemnogo_o_brate_i gore/2010-02-19-1820 